\title{
Rosiglitazone impacts negatively on bone by promoting osteoblast/osteocyte apoptosis
}

\author{
M Alexandra Sorocéanu, Dengshun Miao ${ }^{1}$, Xiu-Ying Bai, \\ Hanyi Su, David Goltzman ${ }^{1}$ and Andrew C Karaplis \\ Department of Medicine and Lady Davis Institute for Medical Research, Sir Mortimer B. Davis-Jewish General Hospital, McGill University, Montréal, \\ Canada H3T 1 E2 \\ ${ }^{1}$ Calcium Research Laboratory and Department of Medicine, McGill University Health Centre and Royal Victoria Hospital, McGill University, Montréal, \\ Canada H3A $1 \mathrm{~A} 1$ \\ (Requests for offprints should be addressed to Andrew C Karaplis, Division of Endocrinology, Sir Mortimer B. Davis-Jewish General Hospital, \\ 3755 Côte Ste Catherine Road, Montréal, Canada H3T 1E2; Email: akarapli@ldi.jgh.mcgill.ca)
}

\begin{abstract}
Thiazolidinediones (TZDs) increase peripheral tissue insulin sensitivity in patients with type 2 diabetes mellitus by activating the nuclear receptor peroxisome proliferatoractivated receptor $\gamma(\operatorname{PPAR} \gamma)$. In bone marrow stromal cell cultures and in vivo, activation of PPAR $\gamma$ by high doses $(20 \mathrm{mg} / \mathrm{kg} /$ day $)$ of TZDs has been reported to alter stem cell differentiation by promoting commitment of progenitor cells to the adipocytic lineage while inhibiting osteoblastogenesis. Here, we have examined the in vivo effects of low-dose rosiglitazone $(3 \mathrm{mg} / \mathrm{kg} /$ day $)$ on bone, administered to mice by gavage for 90 days. Rosiglitazone-treated mice had increased weight when compared with controls, with no significant alterations in serum levels of glucose, calcium or parathyroid hormone $(\mathrm{PTH})$. Bone mineral density (BMD) at the lumbar vertebrae (L1-L4), ilium/sacrum, and total body was diminished by rosiglitazone treatment. Histologically,
\end{abstract}

bone was characterized by decreased trabecular bone volume and increased marrow space with no significant change in bone marrow adipocity. Decreased osteoblast number and activity due to increased apoptotic death of osteoblasts and osteocytes was apparent while osteoclast parameters and serum levels of osteocalcin, alkaline phosphatase activity, and leptin were unaltered by rosiglitazone treatment. Therefore, the imbalance in bone remodeling that follows rosiglitazone administration arises from increased apoptotic death of osteogenic cells and diminished bone formation leading to the observed decrease in trabecular bone volume and BMD. These novel in vivo effects of TZDs on bone are of clinical relevance as patients with type 2 diabetes mellitus and other insulin resistant states treated with these agents may potentially be at increased risk of osteoporosis.

Journal of Endocrinology (2004) 183, 203-216

\section{Introduction}

Thiazolidinediones (TZDs) are a novel class of insulinsensitizing antidiabetic agents. In the USA and Canada, two TZDs are indicated for use in type 2 diabetes mellitus, rosiglitazone and pioglitazone. A third, troglitazone, has been associated with significant hepatotoxicity and has been withdrawn from use. In clinical trials, all three TZDs effectively lower blood glucose levels in monotherapy and in combination therapy with sulfonylureas, metformin and insulin. TZDs improve glucose homeostasis by increasing insulin-stimulated glucose disposal in skeletal muscle (Petersen et al. 2000), although the insulin-sensitizing effects of TZDs on muscle appear to be indirect (Norris et al. 2003). The antidiabetic actions of TZDs are likely mediated by their interaction with the nuclear receptor peroxisome proliferator-activated receptor $\gamma(\operatorname{PPAR} \gamma)$ (Lehmann et al. 1995, Hauner 2002). Adipose tissue is the major expression site for PPAR $\gamma$ (Tontonoz et al. 1994), while much lower levels are observed in other tissues, including other major insulin target tissues, such as liver and skeletal muscle.

$\operatorname{PPAR} \gamma$ exists in two isoforms, PPAR $\gamma 1$ and PPAR $\gamma 2$, products of alternative promoter usage and different splicing (Zhu et al. 1995). Although the functional significance of these splice variants is not yet clear, PPAR $\gamma 1$ isoform is expressed at low levels in most tissues, whereas PPAR $\gamma 2$ is present selectively in fat tissue, where it plays a key role in regulating adipose tissue differentiation (Tontonoz et al. 1994, Shao \& Lazar 1997, Rosen et al. 1999). It is now clear that PPAR $\gamma$, expressed at or below the levels seen in fat tissue, can convert fibroblastic cells into fully differentiated adipocytes and can cause 'transdifferentiation' of cultured myoblasts to adipocytes (Hu et al. 1995). Moreover, the identification of TZDs as ligands for PPAR $\gamma$ has led to the observation that these compounds are potent and effective stimulators of adipogenesis in cells containing 
endogenous or ectopically expressed PPAR $\gamma$ (Lehmann et al. 1995).

The post-natal bone marrow of mammals harbors a population of stem/progenitor cells which are adherent, noncirculating and fibroblastic in nature. Stromal stem cells can give rise to all major skeletal tissues, such as cartilage, myelosupportive stroma, and fibrous connective tissue as well as associated adipocytes and osteoblasts, the bone forming cells (Friedenstein et al. 1968, Owen 1988, Kuznetsov et al. 2001). Commitment to a cell lineage depends on activation of transcription factors that simultaneously suppress gene transcription required for expression of the alternate cell lineage phenotype. In this respect, in vitro studies have indicated that activation of PPAR $\gamma 2$ impacts on marrow stem cell differentiation by increasing adipogenesis while decreasing osteoblastogenesis (LeckaCzernik et al. 1999, 2002). Activated PPAR $\gamma 2$ does this by stimulating adipocyte fatty acid binding protein $(a P 2)$ mRNA expression, a marker of fully differentiated adipocytes, while inhibiting Runt-related transcription factor 2 (Runx2) expression, the main regulator of osteoblast differentiation, as well as suppressing the expression of other markers of osteoblast differentiation, such as $\alpha 1$ (I)collagen, alkaline phosphatase, osteocalcin and osteopontin (Lecka-Czernik et al. 1999). PPAR $\gamma 2$ activation may therefore act as a molecular switch between the osteogenic and adipogenic pathways.

Although the in vitro effects of TZDs on osteoblastogenesis are well recognized, the in vivo consequences of these compounds on bone turnover and bone mineral density (BMD) are less well studied and rather controversial. As a consequence of TZD administration, an increase in the number of bone marrow adipocytes at the expense of the number and differentiation potential of osteoblast progenitors could lead to suppression of bone formation and osteoporosis (Schwartz et al. 2002, Rzonca et al. 2004). Alternatively, improvement of glycemic control by TZDs has been associated with decreased bone turnover (Okazaki et al. 1999a) and increased BMD (Watanabe et al. 2003). Interestingly, decrease in bone turnover occurred prior to significant improvement in glucose metabolism, suggesting that TZDs may have direct effects on bone. It remains unclear, therefore, whether TZDs have a beneficial or detrimental effect on bone. Here, we sought to delineate the in vivo effects of administered low-dose rosiglitazone on the murine skeleton. We show that rosiglitazone impacts negatively on bone remodeling by promoting osteoblast and osteocyte apoptosis. Impairment in bone formation ensues leading to decreased trabecular bone volume and BMD.

\section{Materials and Methods}

\section{Animals}

All animal experiments were reviewed and approved by the institutional animal care committee. Male, non- diabetic C57BL/6 mice were purchased from Charles River (Wilmington, MA, USA) at 4 weeks of age and housed at controlled temperature and humidity with free access to regular chow and water. Following one week of acclimatization, animals were divided in two groups of 27 animals and were gavaged daily for a period of 90 days with either vehicle $(0 \cdot 25 \%$ carboxymethyl cellulose (medium viscosity) aqueous solution $(5 \mathrm{ml} / \mathrm{kg} /$ day)) alone (control group) or vehicle with $3 \mathrm{mg} / \mathrm{kg} /$ day rosiglitazone maleate (Avandia, GlaxoSmithKline, King of Prussia, PA, USA) (rosiglitazone-treated group). Four mice from the control group died during the experimental period from causes unrelated to the treatment. Mice were weighed at baseline and at the indicated time intervals.

\section{$B M D$ measurements and microCT analysis}

$\operatorname{BMD}\left(\mathrm{g} / \mathrm{cm}^{2}\right)$ at the femur, tibia, humerus, ilium and sacrum, lumbar vertebrae (L1-L4), and total body (excluding the head) was measured at 45 and 90 days following initiation of treatment using a Lunar Piximus (GE Lunar, Madison, WI, USA) bone densitometer (variation in repeated measurements calculated to be $\sim 2 \%$ ). Animals were anesthetized with $240 \mathrm{mg} / \mathrm{kg}$ tribromoethanol (Avertin) prior to BMD measurement.

Lumbar vertebrae (L4) were dissected free of soft tissue, fixed overnight in 70\% ethanol and analyzed with a SkyScan 1072 micro-CT scanner and associated analysis software (SkyScan, Antwerp, Belgium). Image acquisition was performed at $100 \mathrm{kV}$ and $98 \mu \mathrm{A}$ with a $0.9^{\circ}$ rotation between frames. During scanning, the samples were enclosed in a tightly fitting rigid plastic rube to prevent movement. Thresholding was applied to the images to segment the bone from the background and the same threshold setting was used for all samples. 2D images were used to generate $3 \mathrm{D}$ reconstructions using the 3D Creator software supplied with the instrument.

\section{Histology and immunohistochemistry}

Mice were sacrificed by cervical dislocation. The lumber vertebral bodies were removed and fixed in PLP fixative (2\% paraformaldehyde containing $0.075 \mathrm{M}$ lysine and $0.01 \mathrm{M}$ sodium periodate solution) for overnight at $4{ }^{\circ} \mathrm{C}$ and processed for histology, as previously described (Miao et al. 2001). Briefly, the lumbar vertebral bodies were decalcified in ethylene-diamine tetra-acetic acid (EDTA) glycerol solution for 5-7 days at $4{ }^{\circ} \mathrm{C}$. Following dehydration and embedding in paraffin, $5 \mu \mathrm{m}$ sections were cut on a rotary microtome. The sections were stained with hematoxylin and eosin (H\&E), and histochemically for total collagen, alkaline phosphatase (ALP) activity and tartrate-resistant acid phosphatase (TRAP) activity. Total collagen was detected in the paraffin sections as described (Lopez-De Leon \& Rojkind 1985), (with minor modifications). De-waxed sections were exposed to $1 \%$ sirius red 
in saturated picric acid for $1 \mathrm{~h}$. After washing with distilled water, the sections were dehydrated and mounted with Biomount medium. Immunohistochemical staining for Bcl-2 (Santa Cruz Biotechnology Inc., Santa Cruz, CA, USA) was performed in paraffin-embedded sections of decalcified vertebral bodies using the avidin-biotinperoxidase complex $(\mathrm{ABC})$ technique.

Enzyme histochemistry for ALP activity was performed as previously described (Miao \& Scutt 2002). Briefly, following preincubation overnight in 1\% magnesium chloride in $100 \mathrm{mM}$ Tris-maleate buffer ( $\mathrm{pH}$ 9.2), de-waxed sections were incubated for $2 \mathrm{~h}$ at room temperature in a $100 \mathrm{mM}$ Tris-maleate buffer containing naphthol AS-MX phosphate $(0.2 \mathrm{mg} / \mathrm{ml})$ (Sigma) dissolved in ethylene glycol monomethyl ether (Sigma) as substrate, and fast red TR $(0.4 \mathrm{mg} / \mathrm{ml})$ (Sigma) as stain for the reaction product. After washing with distilled water, the sections were counterstained with Vector methyl green nuclear counterstain (Vector Laboratories, Burlington, Ontario, Canada), and mounted with Kaiser's glycerol jelly.

For TRAP enzyme histochemistry, de-waxed sections were pre-incubated for $20 \mathrm{~min}$ in buffer containing $50 \mathrm{mM}$ sodium acetate and $40 \mathrm{mM}$ sodium tartrate at $\mathrm{pH}$ $5 \cdot 0$. Sections were then incubated for $15 \mathrm{~min}$ at room temperature in the same buffer containing $2.5 \mathrm{mg} / \mathrm{ml}$ naphthol AS-MX phosphate (Sigma) in dimethylformamide as substrate, and $0.5 \mathrm{mg} / \mathrm{ml}$ fast garnet GBC (Sigma) as color indicator for the reaction product. After washing with distilled water, the sections were counterstained with methyl green and mounted in Kaiser's glycerol jelly (Miao et al. 2002).

\section{Computer-assisted image analysis}

Following histochemical staining of sections, images of fields were photographed using a Sony digital camera. Images of micrographs from single sections were digitally recorded using a rectangular template, and recordings were processed using Northern Eclipse image analysis software, version 5.0 (Empix Imaging Inc., Mississauga, Ontario, Canada). For determining trabecular bone volume/total volume (BV/TV) in collagen stained sections, ALP positive area, and number and size of osteoclasts in TRAP histochemical stained sections, thresholds were set using green and red channels (Miao et al. 2001). Trabecular bone volume was measured in the lumbar vertebral bodies at $\mathrm{x} 25$ magnification while ALP and TRAP parameters were measured in the trabecular region of lumbar vertebral bodies at x 100 magnification.

\section{Detection of apoptotic cells}

De-waxed paraffin sections were stained using an in situ cell death detection kit (Boehringer Mannheim, Indianapolis, IN, USA). Following treatment with $3 \mu \mathrm{g} / \mathrm{ml}$ of proteinase $\mathrm{K}$ for $20 \mathrm{~min}$ at room temperature, bone sections were incubated with a reaction mixture for terminal deoxynucleotidyltransferase-mediated dUTP nick-end-labeling of DNA strand breaks (TUNEL) method for $60 \mathrm{~min}$ at $37^{\circ} \mathrm{C}$. Sections were then incubated with Converter-AP (Boehringer Mannheim) for $30 \mathrm{~min}$ at $37^{\circ} \mathrm{C}$ and alkaline phosphatase activity was visualized after 10-15 min of treatment with Fast Red TR/Naphthol AS-MX phosphate (Sigma), containing $1 \mathrm{mM}$ levamisole to inhibit endogenous alkaline phosphatase activity. Sections were counterstained with methyl green and mounted with Kaiser's glycerol jelly. The number of total apoptotic osteoblasts and osteocytes was counted manually using microscopy and the percentage of apoptotic cells was calculated.

\section{Bone marrow cell cultures}

Tibiae and femurs from mice treated with vehicle or rosiglitazone were removed under aseptic conditions and bone marrow cells were flushed out with DMEM containing $10 \%$ FCS, $50 \mu \mathrm{g} / \mathrm{ml}$ ascorbic acid, $10 \mathrm{mM}$ $\beta$-glycerophosphate and $10^{-8} \mathrm{M}$ dexamethasone. Cells were dispersed by repeated pipetting and a single cell suspension was achieved by forcefully expelling the cells through a 22-gauge syringe needle. Total bone marrow cells $\left(10^{6}\right)$ were cultured in $36-\mathrm{cm}^{2}$ dishes in $5 \mathrm{ml}$ of the above-mentioned medium. The medium was changed every 4 days and cultures were maintained for 18 days. At the end of the culture period, cells were washed with PBS, fixed with PLP fixative and stained cytochemically for alkaline phosphatase (ALP). Following staining, ALP positive colony forming units $\left(\mathrm{CFU}-\mathrm{f}_{\mathrm{ALP}}\right)$ were counted manually.

Blood and serum biochemistry Following collection, blood glucose was measured using a Glucometer Elite kit (Bayer Canada, Inc., Toronto, Ontario, Canada) and serum samples were aliquoted and stored at $-70{ }^{\circ} \mathrm{C}$ until assayed. Serum levels of osteocalcin were determined using an immunoradiometric assay (Immutopics, Inc., San Clemente, CA, USA), ALP activity using an absorbtivity kit (Sigma Diagnostics), calcium using a colorimetric determination kit (Sigma Diagnostics), intact parathyroid hormone (PTH) using an enzyme-linked immunosorbent assay (Immutopics, Inc., San Clemente, CA, USA), and leptin using an enzyme immunometric assay (Assay Designs Inc., Ann Arbor, MI, USA).

\section{Statistics}

BMD and histochemical results were analyzed by GraphPad Prism (GraphPad Software Inc., San Diego, CA, USA) using an unpaired $t$-test. Results were expressed as mean \pm S.E.M. The difference was considered statistically significant when $P<0 \cdot 05$. 


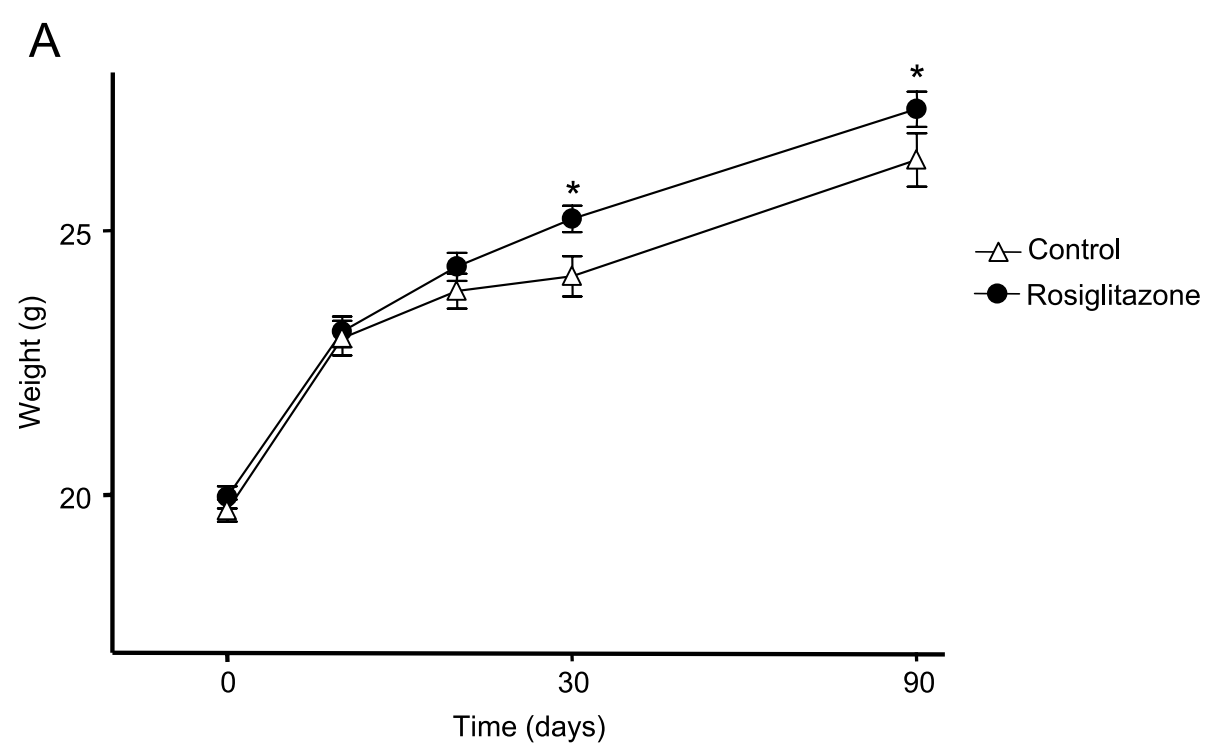

B
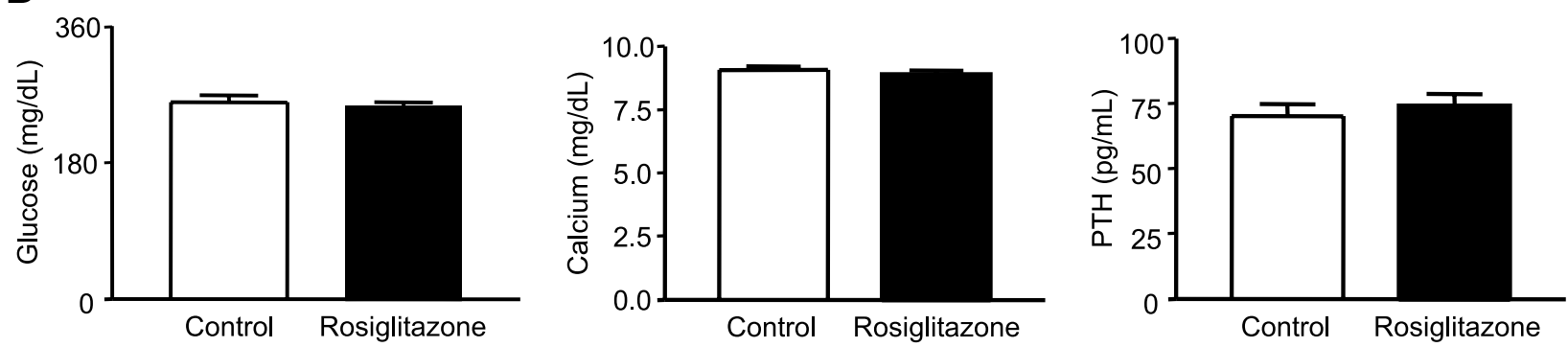

Figure 1 Effects of rosiglitazone on body weight, blood glucose, and serum parameters of calcium homeostasis. (A) Rosiglitazone treatment increases body weight. The weight shown is the mean weight (g) \pm S.E.M., $n=23$ for the control group, $n=27$ for rosiglitazone-treated group; * $P<0.05$ at 45 and 90 days of treatment. (B) Effect of rosiglitazone on blood and serum biochemistry. There was no difference in blood glucose and serum levels of calcium and PTH between vehicle-treated control (open bars) and rosiglitazone-treated (solid bars) mice ( $n=12-22$ and $14-22$, respectively, depending on the assay).

\section{Results}

\section{Rosiglitazone increases body weight}

For the entire duration of treatment, mice from both control- and rosiglitazone-treated groups gained weight (Fig 1A). At the beginning of the experiment, both groups were similar weight $(19 \cdot 70 \pm 0 \cdot 21 \mathrm{~g}$ for the control group, $19 \cdot 95 \pm 0.20 \mathrm{~g}$ for the rosiglitazone-gavaged group). However, following the fourth week of treatment, a weight difference became apparent, as the rosiglitazonegavaged group gained more weight than control animals. By the sixth week of treatment the difference in weight became statistically significant $(24 \cdot 17 \pm 0.38 \mathrm{~g}$ and $25 \cdot 23 \pm 0 \cdot 25 \mathrm{~g}$ for the control group and the rosiglitazone treated group, respectively, $P<0.05)$ and was maintained until the end of the 12 week treatment period $(26.35 \pm 0.51 \mathrm{~g}$ and $27.31 \pm 0.33 \mathrm{~g})$. The increase in weight for the rosiglitazone-treated group compared with the control group was $3 \cdot 5 \%$ of body weight.

\section{Rosiglitazone does not alter serum biochemistry}

Blood and serum samples were collected following 90 days of treatment and assayed for glucose, calcium and PTH. As seen in Fig. 1B, no significant difference was observed in blood glucose levels $(261.4 \pm 9 \cdot 0 \mathrm{mg} / \mathrm{dL}$ and $255.5 \pm$ $5.9 \mathrm{mg} / \mathrm{dL})$, levels of serum calcium $(9.09 \pm 0.16 \mathrm{mg} / \mathrm{dL}$ and $8.91 \pm 0.15 \mathrm{mg} / \mathrm{dL})$ and PTH $(70 \cdot 30 \pm 4.65 \mathrm{pg} / \mathrm{mL}$ and $74.39 \pm 4.45 \mathrm{pg} / \mathrm{mL}$ ) between the control group and rosiglitazone-treated group, respectively.

\section{Rosiglitazone treatment decreases BMD}

BMD was measured at 45 and 90 days following initiation of treatment. At 45 days, no statistically significant difference in BMD between the two groups was observed. However, as shown in Fig. 2A, following 90 days of treatment a significant decrease in BMD measurements was observed at the lumbar vertebrae, ilium/sacrum and total body in the rosiglitazone-gavaged group compared 
A Lumbar vertebrae (L1-L4)

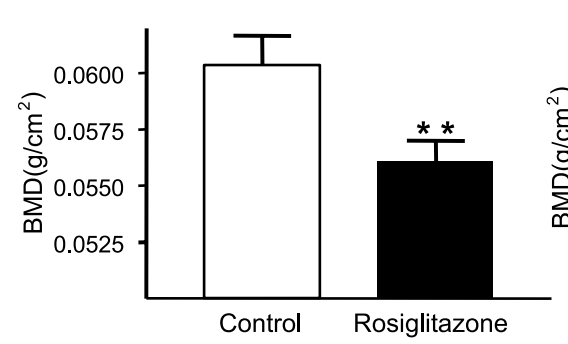

B

Lumbar vertebrae (L1-L4) BMD over time

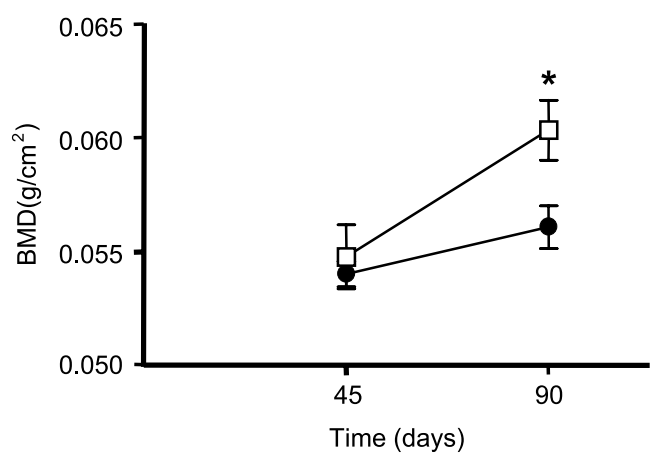

Ilium and sacrum

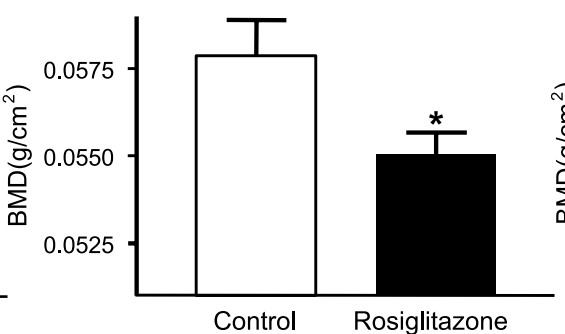

Total body

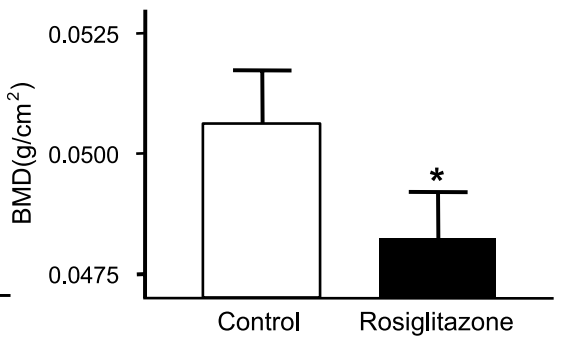

Ilium and sacrum BMD over time

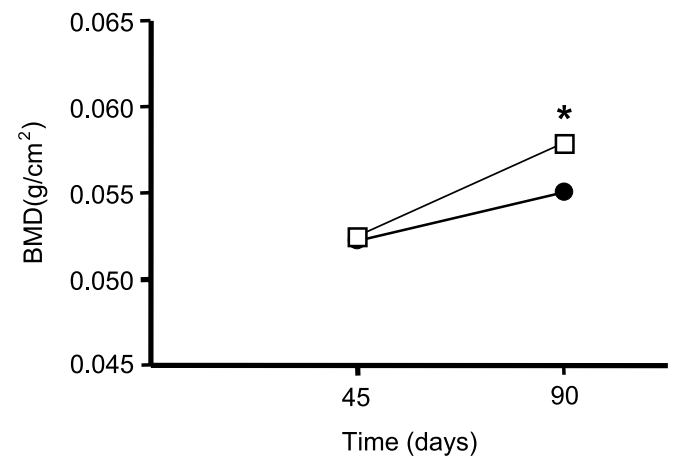

Figure 2 Effect of rosiglitazone treatment on BMD. (A) BMD at the lumbar vertebrae (L1-L4), the ilium/sacrum, and total body BMD. The data shown are the mean BMD $\left(\mathrm{g} / \mathrm{cm}^{2}\right) \pm$ S.E.M., $n=23$ for control group and $n=27$ for rosiglitazone-treated group measured following 90 days of treatment; ${ }^{*} P<0 \cdot 05,{ }^{* *} P<0 \cdot 01$. (B) Evolution of BMD over time at the lumbar vertebrae (L1-L4) and ilium/sacrum. The data are the mean \pm S.E.M. BMD after 45 and 90 days of treatment; ${ }^{*} P<0 \cdot 05$. $\square$, control; $\bullet$, rosiglitazone.

with the controls. BMD at lumbar vertebrae (L1-L4) of rosiglitazone-treated mice was $7 \cdot 08 \%$ lower than that of controls $\left(0 \cdot 05608 \pm 0 \cdot 00093 \mathrm{~g} / \mathrm{cm}^{2}\right.$ vs $0.06035 \pm$ $0 \cdot 00132 \mathrm{~g} / \mathrm{cm}^{2}$, respectively), $4 \cdot 87 \%$ lower at the ilium/ sacrum $\quad\left(0 \cdot 05505 \pm 0.00062 \mathrm{~g} / \mathrm{cm}^{2} \quad\right.$ vs $0.05787 \pm$ $0.00103 \mathrm{~g} / \mathrm{cm}^{2}$ ) and $4.72 \%$ lower for total body $\left(0 \cdot 04823 \pm 0 \cdot 00098 \mathrm{~g} / \mathrm{cm}^{2}\right.$ vs $\left.0 \cdot 05062 \pm 0 \cdot 00112 \mathrm{~g} / \mathrm{cm}^{2}\right)$. Differences in measured BMD were also observed between the two groups at the tibia, femur and humerus, although they did not reach statistical significance.

\section{Rosiglitazone impairs BMD accretion}

A different evolution of BMD over time was apparent in the rosiglitazone-treated mice compared with controls. As shown in Fig. 2B, BMD increase over time had a steeper slope for the control group than the treated animals at the lumbar vertebrae (L1-L4) and ilium/sacrum. Measured at 45 and 90 days following treatment initiation, lumbar vertebral BMD increased from $0.05477 \mathrm{~g} / \mathrm{cm}^{2}$ to $0.06035 \mathrm{~g} / \mathrm{cm}^{2}$, an increase of $0.00558 \pm 0.00149 \mathrm{~g} / \mathrm{cm}^{2}$, or $10 \cdot 18 \%$ over 45 days, whereas for the rosiglitazonetreated group the lumbar vertebrae BMD progressed from $0.05401 \mathrm{~g} / \mathrm{cm}^{2}$ to $0.05608 \mathrm{~g} / \mathrm{cm}^{2}$, an increase of only
$0 \cdot 00207 \pm 0 \cdot 00078 \mathrm{~g} / \mathrm{cm}^{2}$ or $3 \cdot 83 \%$ over the same time period. Similarly, ilium/sacrum BMD measured at 45 days and 90 days following treatment initiation went from $0.05245 \mathrm{~g} / \mathrm{cm}^{2}$ to $0.05787 \mathrm{~g} / \mathrm{cm}^{2}$ in the control group, which represents an increase of 0.00542 $\pm 0.00105 \mathrm{~g} / \mathrm{cm}^{2}$ or $10.33 \%$, while in the case of the rosiglitazone-treated animals the change was less pronounced, increasing from $0.05224 \mathrm{~g} / \mathrm{cm}^{2}$ to $0.05505 \mathrm{~g} / \mathrm{cm}^{2}$; an increase of only $0 \cdot 00281 \pm 0.00072 \mathrm{~g} / \mathrm{cm}^{2}$ or $5 \cdot 38 \%$. These findings indicate that rosiglitazone administration negatively influences BMD accretion. Although similar changes were observed for BMD evolution at the femur, tibia, humerus and total body between the two groups, they did not reach statistical significance.

\section{Rosiglitazone treatment decreases trabecular bone volume}

To further investigate the observed BMD changes that result from 90 days of rosiglitazone treatment, histological sections were prepared from lumbar vertebrae. Shown in Fig 3A, histological sections of lumbar vertebra (L4) illustrate a loss in trabecular bone volume in the rosiglitazone-treated mice at three months when compared with the control group. In rosiglitazone- treated 
mice the trabeculae were thinner and an increase in trabecular separation was observed. In parallel, an increase in the bone marrow space was apparent. When quantified by histomorphometry, a statistically significant decrease of $22.6 \%$ in trabecular bone volume $\mathrm{BV} / \mathrm{TV}$ was observed in the rosiglitazone-treated bone specimens compared with controls (Fig. 3B). Therefore, the observed BMD changes following rosiglitazone administration are in part due to a decrease in trabecular bone volume. Interestingly, a trend toward a corresponding increase in bone marrow fat content was apparent, although statistical significance was not attained (Fig. 3C). The observed alterations in trabecular bone content and architecture (trabecular number, thickness and separation) following rosiglitazone treatment were further confirmed by micro CT analysis (Table 1). Decreases in cortical bone volume were also apparent but did not attain statistical significance.

\section{Rosiglitazone negatively influences bone formation}

Decreases in bone volume can arise either from an increase in bone resorption or a decrease in bone formation, processes that are regulated primarily by osteoclasts and osteoblasts, respectively. We therefore sought to determine which of these processes was altered by rosiglitazone treatment. TRAP activity which is expressed by active osteoclasts and therefore serves as a marker of osteoclast activity, was similar in histochemically-stained bone sections from rosiglitazone-treated and control animals (Fig. 4A). Moreover, using computer-assisted histomorphometric analysis, no difference was observed between the two groups in the number of TRAP positive osteoclasts/field $(58 \cdot 2 \pm 3 \cdot 2$ for controls vs $62 \cdot 3 \pm 3 \cdot 3$ for the rosiglitazonetreated group) and in the average size of TRAP positive osteoclasts $\left(37 \cdot 8 \pm 2 \cdot 0 \mu \mathrm{m}^{2}\right.$ for control vs $39 \pm 0.9 \mu \mathrm{m}^{2}$ for the rosiglitazone-treated group) (Fig. 4B).

In sharp contrast, histochemical staining for ALP activity, which localizes on the surface of osteoblasts and serves as marker of osteoblast activity, was decreased in the rosiglitazone-treated bone specimens when compared with the control group (Fig. 5A). In addition, the number of osteoblasts per tissue area was $51.6 \%$ lower in the rosiglitazone-treated group $\left(45 \pm 4 \cdot 6 / \mathrm{mm}^{2}\right.$ vs $93 \pm 9 \cdot 6 /$ $\mathrm{mm}^{2}$ for the control group), an observation that was corroborated by quantification of the total number of ALP-positive area/tissue area $(1 \cdot 61 \pm 0 \cdot 10 \%$ for controls vs $0 \cdot 34 \pm 0.05 \%$ for the rosiglitazone-gavaged group, $P<0 \cdot 001)$. Finally, in vivo labeling of bones with calcein demonstrated a marked decrease in mineral apposition rate (MAR), a parameter of bone formation, following rosiglitazone treatment $(0 \cdot 81 \pm 0.03$ for controls vs $0.59 \pm 0.02$ for rosiglitazone-treated group, $P<0 \cdot 05$ ) (Fig. 5B). These findings demonstrate that the observed decrease in trabecular bone volume and BMD following rosiglitazone administration arises primarily from its negative impact on parameters of bone formation, namely osteoblast number and function, rather than from an increase in bone resorption.

Low-dose rosiglitazone does not alter bone marrow stem cell commitment

To elucidate whether the observed decrease in bone formation arises in part from impaired commitment of bone marrow stem cells to the osteogenic lineage, ex vivo bone marrow cultures were prepared from control and rosiglitazone-treated mice. Compared with controls, rosiglitazone cultures repeatedly demonstrated an equivalent capacity to differentiate to $\mathrm{CFU}-\mathrm{f}_{\mathrm{ALP}}(\sim 30 \%$ of total CFU-f) (results not shown). Therefore, low-dose rosiglitazone does not negatively influence bone formation by decreasing the commitment of bone marrow precursors toward osteogenic differentiation.

\section{Increased osteoblast/osteocyte apoptosis due to rosiglitazone treatment}

Next, we sought to identify an alternate mechanism by which osteoblast biology is deranged by low-dose rosiglitazone administration. Rosiglitazone could influence osteoblast/osteocyte survival, leading to the observed decrease in osteogenic cell number. Using TUNEL staining, an increased number of apoptotic osteoblasts and osteocytes were indeed observed in bone specimens from rosiglitazone-treated mice (Fig. 6A) and the percentage of apoptotic osteoblasts/osteocytes was increased nearly 5-fold compared with controls (Fig. 6B). Moreover, Bcl-2 immunoreactivity in osteogenic cells was diminished following treatment with rosiglitazone (Fig. 6C). Therefore, one way that rosiglitazone impacts negatively on bone formation is by decreasing Bcl-2 expression in osteoblasts and osteocytes thereby promoting their apoptotic death.

\section{Rosiglitazone treatment does not alter serum markers}

Serum samples collected following 90 days of treatment with rosiglitazone were assayed for ALP activity (57.84 $\pm 3.16 \mathrm{U} / \mathrm{L}$ and $54.83 \pm 3.47 \mathrm{U} / \mathrm{L}$ ), and osteocalcin $(19.65 \pm 1.11 \mathrm{ng} / \mathrm{mL}$ and $20.50 \pm 0.54 \mathrm{ng} / \mathrm{mL})$, which were similar in the two groups (Fig. 7). Serum levels of leptin, a marker for adipocyte function/differentiation, was also measured. Again, no significant difference was observed between control and rosiglitazone-treated animals $(815 \cdot 10 \pm 57.94 \mathrm{pg} / \mathrm{mL}$ and $801.90 \pm 63.48 \mathrm{pg} / \mathrm{mL}$, respectively).

\section{Discussion}

In this study, we sought to delineate the in vivo consequences of low-dose rosiglitazone $(3 \mathrm{mg} / \mathrm{kg} /$ day) 


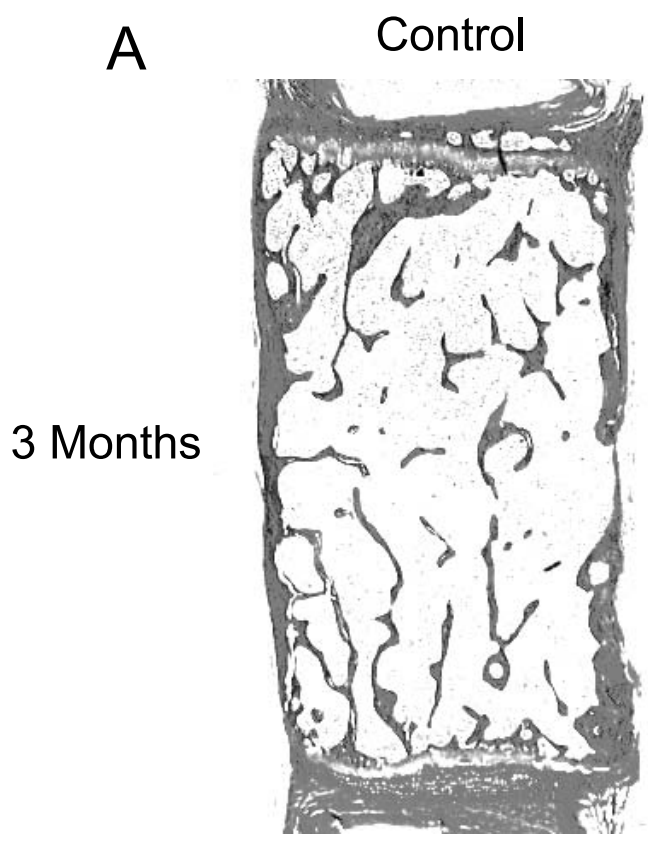

\section{Rosiglitazone}

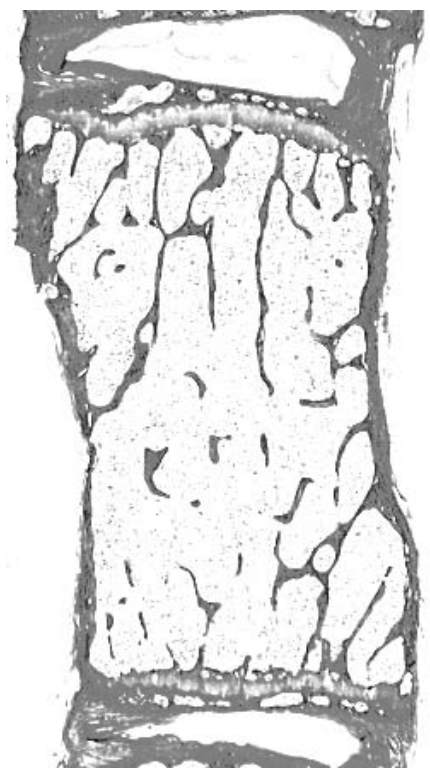

B

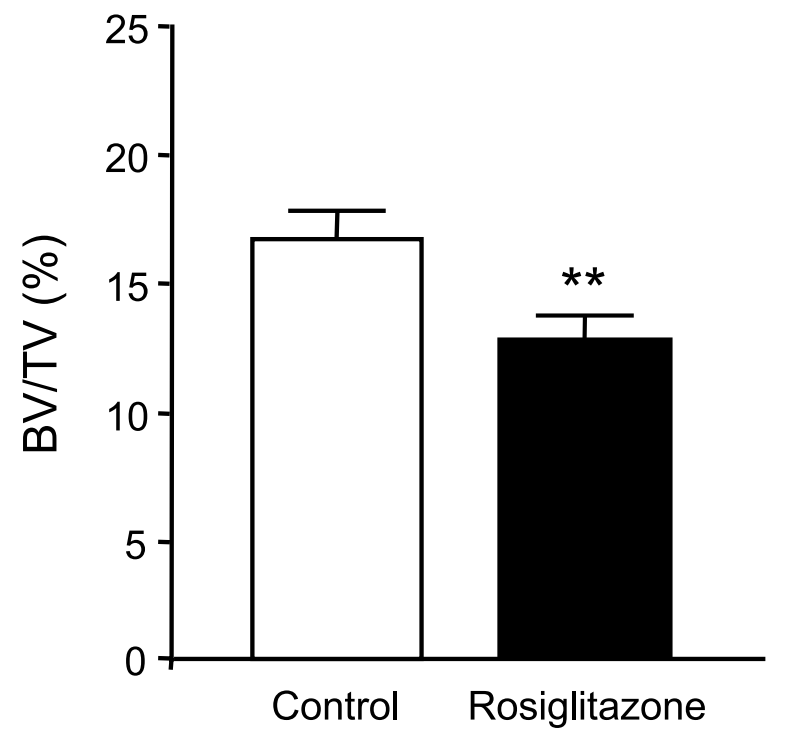

C

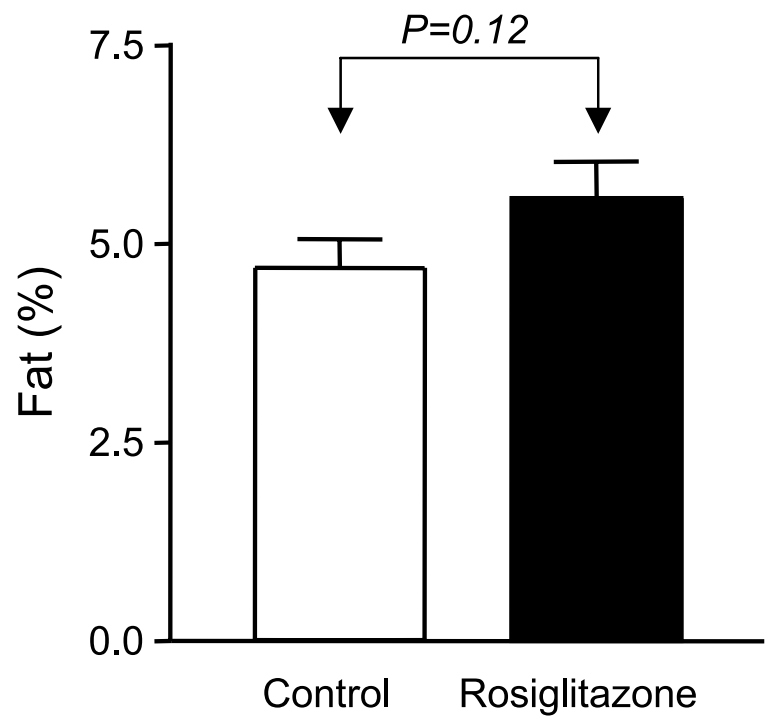

Figure 3 Vertebrae histology and histomorphometry (A) Histological sections of lumbar vertebra (L4) from control and rosiglitazone-gavaged animals. Sections were stained with H\&E and are representative of 3-6 sections obtained from all lumbar vertebrae. (B) Histomorphometric analysis of bone volume/total volume (BV/TV), a measure of trabecular bone content, at L4. The data shown are the mean \pm S.E.M., $n=6$; * $P<0 \cdot 05$. (C) Bone marrow fat content (\%), as determined by densitometric analysis. The data shown are the mean \pm S.E.M., $n=23$ for control group and $n=27$ for the rosiglitazone group; $P=0 \cdot 12$.

administration on BMD and parameters of bone turnover in the murine skeleton. We demonstrate that a 3-month oral treatment with rosiglitazone in mice profoundly diminishes osteoblast/osteocyte number and activity by decreasing Bcl-2 expression and thereby promoting their apoptotic death. This leads to diminished bone formation and the observed decrease in trabecular bone volume and BMD. Our findings therefore raise the potential concern that long-term use of TZDs in patients with type 2 diabetes mellitus and other insulin-resistant states may 
Table 1 Quantitative assessment by microCT of trabecular architecture and cortical bone thickness in vertebrae from control and rosiglitazone-treated mice

\begin{tabular}{|c|c|c|c|c|c|}
\hline & $\begin{array}{l}\text { BV/TV } \\
(\%)\end{array}$ & $\begin{array}{l}\text { Tb.N } \\
(1 / \mathrm{mm})\end{array}$ & $\begin{array}{l}\text { Tb.Th } \\
(\mathrm{mm})\end{array}$ & $\begin{array}{l}\text { Tb.Sp } \\
(\mathrm{mm})\end{array}$ & $\begin{array}{l}\text { Cortical } \\
\text { thickness } \\
(\mathrm{mm})\end{array}$ \\
\hline Rosiglitazone & $0 \cdot 091 \pm 0.013^{*}$ & $3 \cdot 12 \pm 0 \cdot 11^{*}$ & $0.047 \pm 0.003^{*}$ & $0 \cdot 275 \pm 0.008^{*}$ & $0 \cdot 169 \pm 0 \cdot 003$ \\
\hline
\end{tabular}

Tb.N, trabecular number; Tb.Th, trabecular thickness; Tb.Sp, trabecular spacing. The data are mean \pm S.E.M. after 90 days of treatment; ${ }^{\star} P<0 \cdot 05$ for rosiglitazone vs control ( $n=7$ per group).

have negative consequences on skeletal homeostasis, leading to decreased bone strength and propensity for fragility fractures.

In our study, blood glucose and biochemical parameters of calcium homeostasis were unaltered by TZD treatment. Interestingly, the weight of mice in both control and rosiglitazone-treated groups increased over time. This advocates that the animals were healthy and experiencing a normal growth pattern. Therefore, the changes that arose in bone as a consequence of rosiglitazone treatment were not due to nutritional deficiency or other health problems. In fact, following 90 days of treatment, the rosiglitazonegavaged group had an increase in body weight $3.65 \%$ higher than the control group, concordant with what has been the clinical experience in patients with type 2 diabetes mellitus treated with TZDs. Indeed, administration of rosiglitazone has been associated with a weight gain of $0.7-3.5 \mathrm{~kg}$ in treated patients (Malinowski \& Bolesta 2000). The weight gain may be due to increased deposition of subcutaneous fat (Kawai et al. 1999, Kelly et al. 1999), water retention (Niemeyer \& Janney 2002) and increased food intake (Shimizu et al. 1998).

In vitro, TZDs promote bone marrow stromal cell adipogenesis at the expense of osteogenesis (Gimble et al. 1996, Lecka-Czernik et al. 1999). It was therefore expected that the compound's capacity to activate PPAR $\gamma$ would diminish osteoblast differentiation while increasing bone marrow adipogenesis, as substantiated recently in vivo (Rzonca et al. 2004). Indeed, in our studies, osteoblast number and parameters of cell function were profoundly decreased by TZD administration. However, the anticipated increase in bone marrow adiposity was not apparent, although a trend toward it was evident. Moreover, we did not observe altered differentiation in ex vivo cultured bone marrow stromal cells from mice treated with low-dose rosiglitazone. Several explanations could account for our findings. First, reciprocal changes in adipogenesis and osteoblastogenesis are not an inevitable consequence of PPAR $\gamma 2$ activation. For example, rosiglitazone, the TZD that binds most efficiently to PPAR $\gamma 2$ (its affinity being nearly 10 times higher than that of troglitazone) (Camp et al. 2000), activates both proadipogenic and antiosteoblastogenic pathways. However, the thiazolidine acetamide ligand GW0072 [( \pm )-(2S,5S)-4-(4-(4- carboxyphenyl)butyl)-2-heptyl-4-oxo-5-thaizolidine N,Ndibenzyl-acetamide] is antiosteogenic without stimulating adiposity differentiation. Troglitazone on the other hand, induces proliferation and differentiation of committed adipocyte precursors without affecting the mesenchymal stem cells and osteoblast differentiation (Tornvig et al. 2001). Therefore, activation of PPAR $\gamma 2$ in vitro may stimulate adipocyte differentiation, suppress osteoblast differentiation or exhibit both activities, depending on the activating ligand (Lecka-Czernik et al. 2002). Second, adipose tissue at different sites may have distinct responses to TZDs. For instance, treatment with TZDs increases subcutaneous adipose tissue while decreasing intraabdominal fat accumulation (Adams et al. 1997, Mori et al. 1999). Third, the dose of rosiglitazone administered here may have been too low to significantly increase adipocyte differentiation in bone marrow stem cells but sufficiently high to induce osteoblast/osteocyte apoptosis. Indeed, the $3 \mathrm{mg} / \mathrm{kg} /$ day dose of rosiglitazone used here is much lower than the $20 \mathrm{mg} / \mathrm{kg}$ /day employed by Rzonca and co-workers (Rzonca et al. 2004) in their studies that demonstrated an increase in bone marrow adiposity. Therefore, the effects of TZDs on bone marrow adiposity may be dose-dependent. Finally, adipogenesis and osteoblastogenesis may be independent processes, as previously suggested (Tornvig et al. 2001), whereby the increase in bone marrow adipogenesis is a passive process where adipocytes occupy the space left by the absent trabecular bone elements (Nuttall \& Gimble 2000).

The mechanism by which TZDs alter osteoblast number and function is likely multifactorial and mediated through activation of PPAR $\gamma$-dependent pathways, although mechanisms that are PPAR $\gamma$-independent need also be considered. Previous studies have suggested that TZDs affect the early steps of osteogenic differentiation (Paulik \& Lenhard 1997, Jackson \& Demer 2000, Rzonca et al. 2004). Our finding that rosiglitazone treatment increases osteogenic cell apoptosis provides a novel explanation for the observed decrease in bone formation that follows administration of this compound in mice. Moreover, it substantiates previous in vivo evidence for the proapoptotic effect of TZDs on tumor cell growth (Elstner et al. 1998, Heaney et al. 2003) and in vitro reports showing that TZDs can induce apoptosis in diverse cell types 

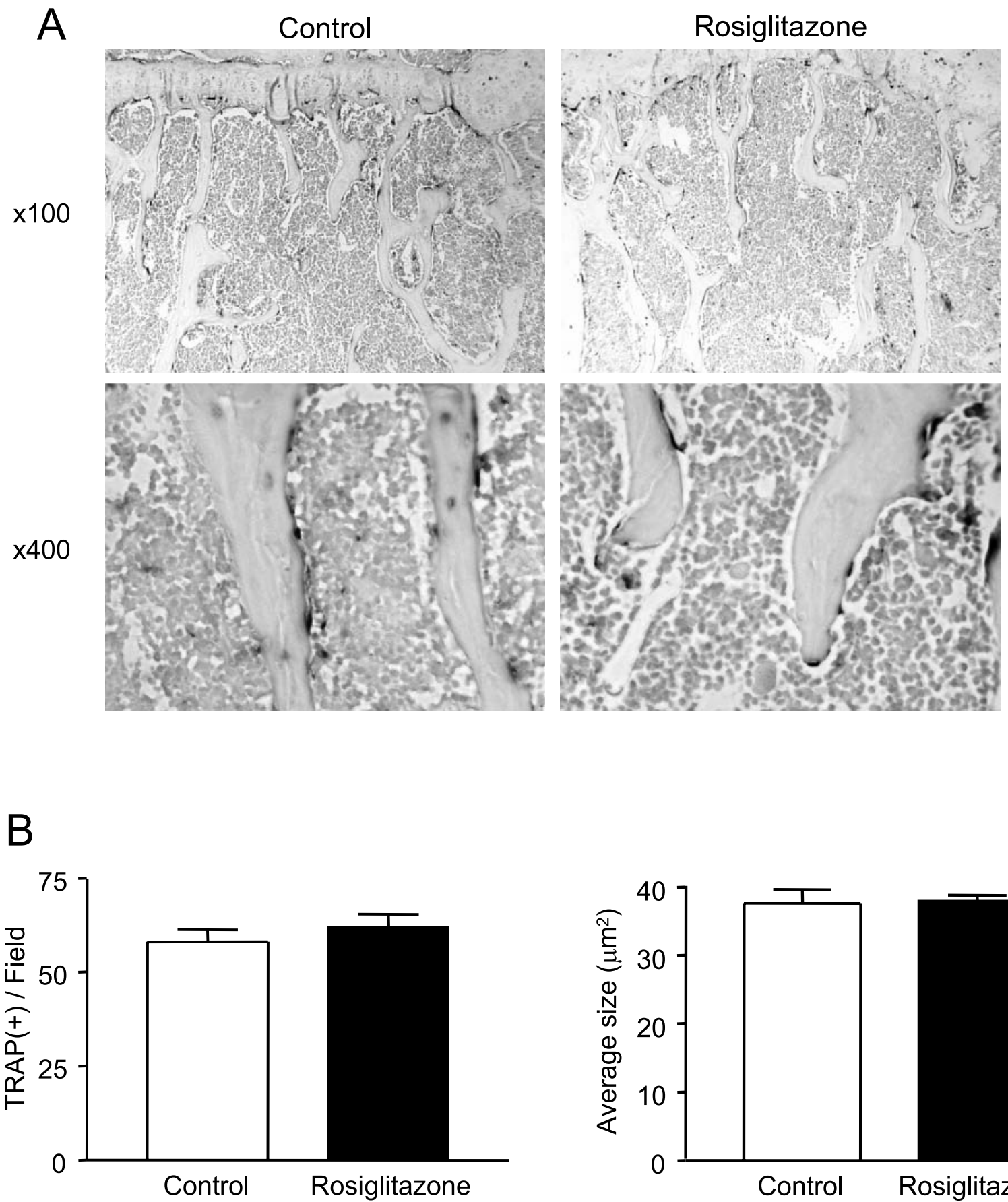

Figure 4 Rosiglitazone and osteoclasts. (A) Coloration of TRAP activity, a marker of osteoclast activity for control and rosiglitazone-gavaged groups. Upper panels, x 100; lower panels, x 400. Stained sections of lumbar vertebra (L4) are representative of eight determinations. (B) Computer-assisted image analysis of the number and size of TRAP positive osteoclasts per field. The data shown are the mean \pm S.E.M. of 12 readings.

including endothelial cells (Bishop-Bailey \& Hla 1999), vascular smooth muscle cells (Okura et al. 2000), monocyte-derived macrophages (Chinetti et al. 1998) and various human cancer cells (Elstner et al. 1998, Takahashi et al. 1999, Chang \& Szabo 2000, Eibl et al. 2001). Interestingly, the in vivo proapoptotic effects of rosiglitazone on pituitary tumor cells required the oral administration of high doses of rosiglitazone $(20-50 \mathrm{mg} / \mathrm{kg} /$ day $)$, 
A

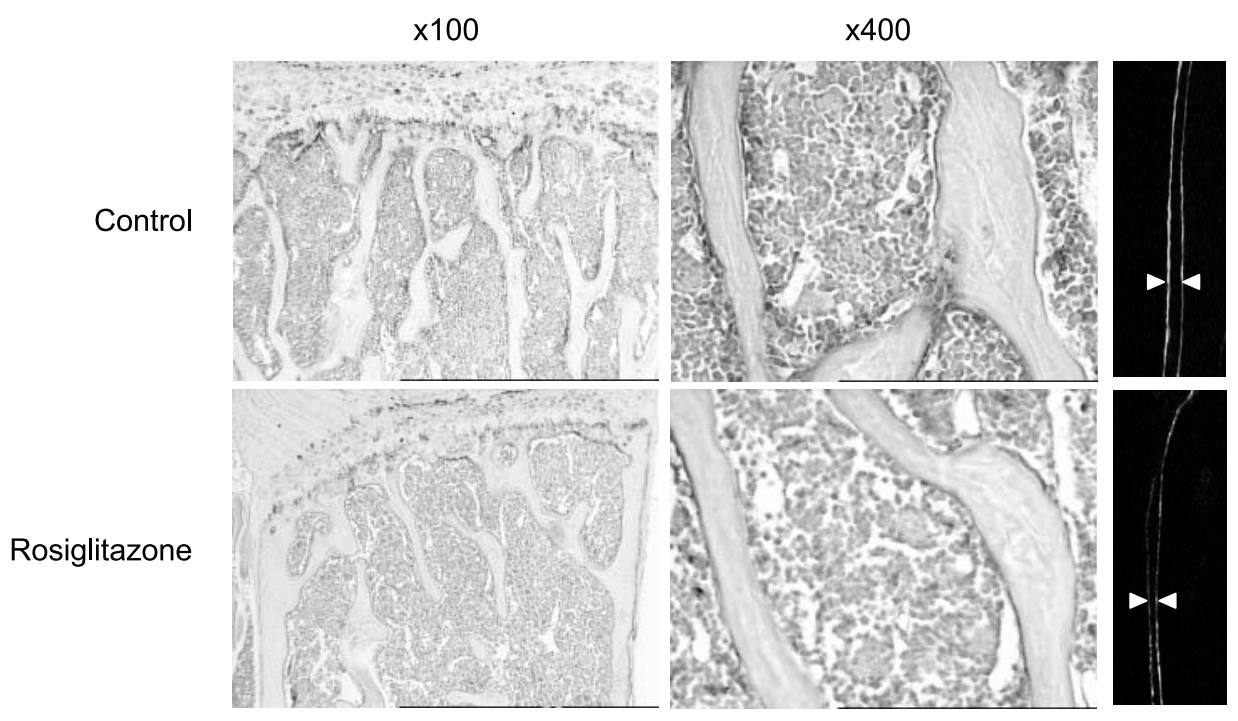

B
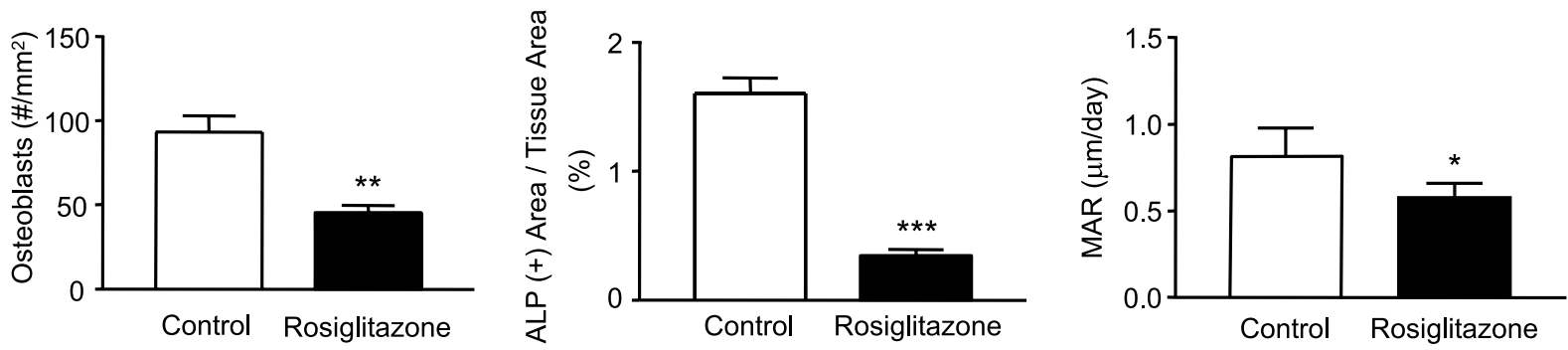

Figure 5 Effects of rosiglitazone on osteoblast parameters. (A) Immunoenzymatic detection of alkaline phosphatase (ALP) activity for vehicle- and rosiglitazone-gavaged mice. Left panels, x 100; middle panels, x 400. Stained sections of lumbar vertebra (L4) are representative of six determinations. Right panels, in vivo calcein labeling of bones; distance between arrowheads represents the MAR (B) Computer-assisted image analysis of osteoblasts per tissue area, ALP positive area per tissue area, and MAR. The data shown are the mean \pm S.E.M. of 11 readings. ${ }^{*} P<0 \cdot 05,{ }^{* *} P<0 \cdot 01,{ }^{* *} P<0 \cdot 001$.

while lower doses (5 mg/kg/day) were ineffective (Heaney et al. 2003). On the other hand, a significant reduction in the in vivo growth of MKN45 gastric cells in nude mice was reported after treatment with $6 \mathrm{mg} / \mathrm{kg} /$ day of rosiglitazone (Leung et al. 2004). This compares favorably with our observation that an oral dose of $3 \mathrm{mg} / \mathrm{kg} /$ day induced pronounced proapoptotic action on osteoblasts, indicating perhaps a higher sensitivity of these skeletal cells to the cellular actions of rosiglitazone. Although the molecular mechanisms by which TZDs induce apoptosis remain to be defined, our findings would indicate that activation of PPAR $\gamma$ leads to cell growth arrest and apoptosis, at least in part, by reducing Bcl-2 expression. This is corroborated by the recent observation that TZDs induce $G_{0}-G_{1}$ cell-cycle arrest and apoptosis (Heaney et al. 2003) by decreasing Bcl-2 and increasing Bax expression (Heaney et al. 2003, Yokoyama et al. 2003), and inducing transcription of the growth arrest and
DNA damage-inducible 45 (GADD45) gene (Bruemmer et al. 2003). Further studies will be required to substantiate whether these additional molecular mechanisms underlie the proapoptotic effects of rosiglitazone on osteoblasts.

It is noteworthy that our findings with respect to serum leptin levels do not differ from what has been reported in other studies. TZDs transcriptionally inhibit leptin expression in adipocytes (Zhang et al. 1996) and serum leptin levels decrease (Boden et al. 2003, Watanabe et al. 2003) or remain unchanged (Satoh et al. 2003) following TZD administration in patients with type 2 diabetes mellitus. The change of BMD in these patients correlated negatively with that of serum leptin, a potent inhibitor of bone mass accretion (Ducy et al. 2000). Yet, percent changes in BMD were not significantly higher in nondiabetic subjects (Watanabe et al. 2003). It is possible that the dose of rosiglitazone administered here might have been too low to show a change in leptin expression. In rats, 

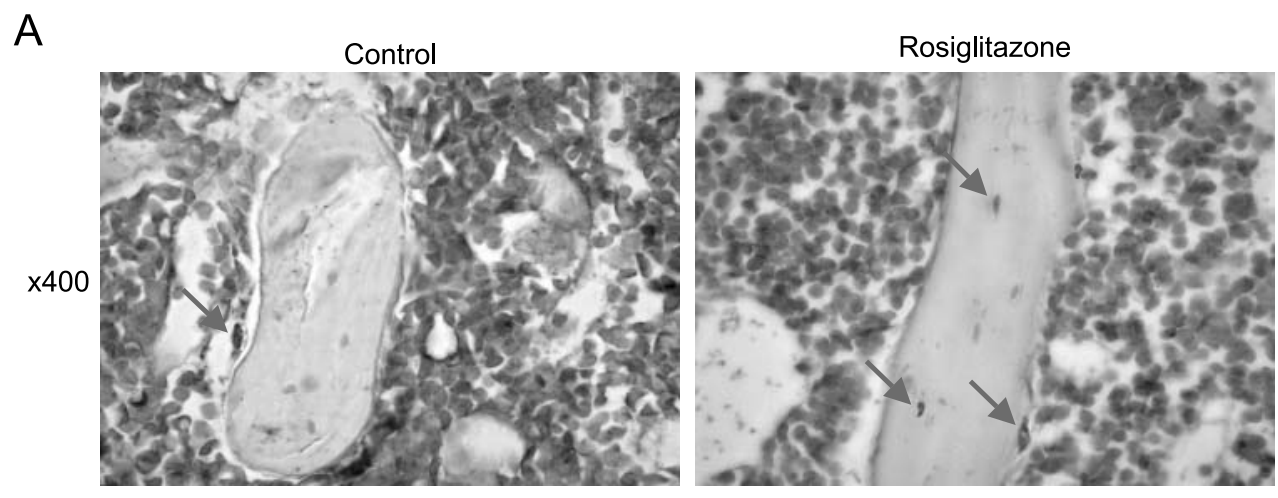

B

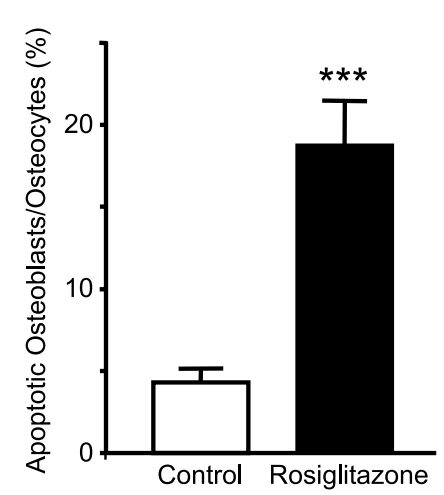

C

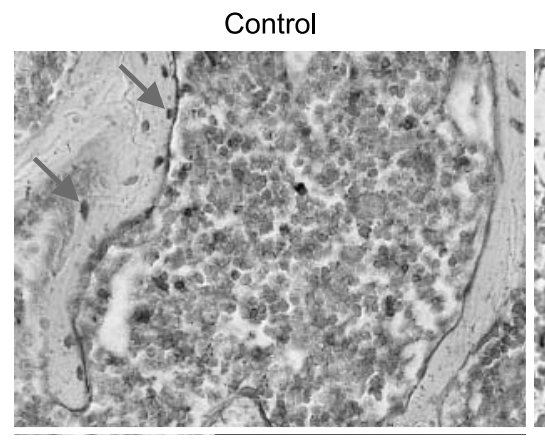

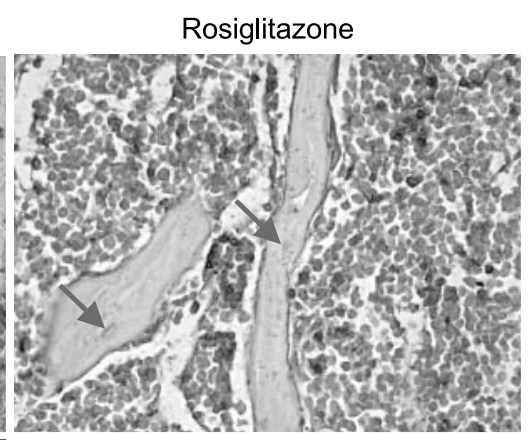

Figure 6 Osteogenic cell apoptosis following rosiglitazone administration. (A) Increased numbers of apoptotic osteoblasts and osteocytes were detected (arrows) following TUNEL staining in bone sections of lumbar vertebra (L4) from rosiglitazone-treated animals compared with control specimens. (B) The number of apoptotic osteogenic cells in rosiglitazone-treated and control bone sections was quantified. Twelve samples from each group have been used for image analysis, ${ }^{* * *} P<0 \cdot 001$. (C) Bcl-2 immunoreactivity in trabecular bone of lumbar vertebra (L4) from control and rosiglitazone-treated mice. Shown are micrographs from representative stained sections from three different animals in each group.

administration of rosiglitazone at doses of $2-5 \mathrm{mg} / \mathrm{kg} /$ day or higher decreased leptin mRNA levels in adipose tissue (De Vos et al. 1996). Yet, doses of $20 \mathrm{mg} / \mathrm{kg} /$ day in mice also failed to increase serum leptin levels, despite increases in bone marrow and brown fat content (Rzonca et al. 2004). Therefore, it is likely that a change in leptin expression does occur in adipose tissue, but is not reflected in circulating serum leptin levels.
Finally, our results do not support published in vitro findings suggesting that TZDs inhibit osteoclast formation (Okazaki et al. 1999b, 2000). As illustrated by TRAP staining and histomorphometric assessment of osteoclast number and surface area, rosiglitazone failed to alter these parameters under the in vivo conditions of our study. These observations could be explained in part by the type of TZD used (troglitazone vs rosiglitazone) and/or the
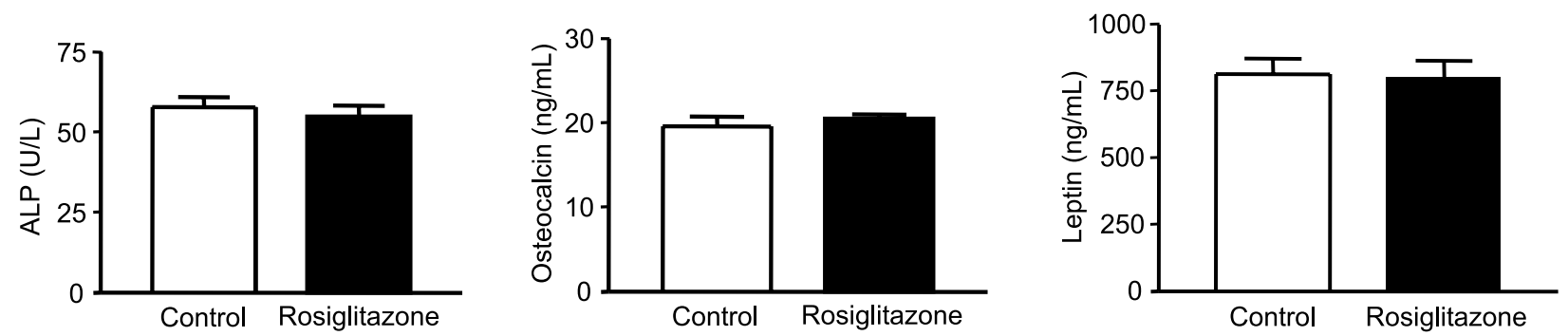

Figure 7 Serum markers of bone and adipose tissue metabolism. Serum levels of ALP activity and osteocalcin (bone formation markers), and leptin (adipocity marker) in vehicle- and rosiglitazone-treated mice. Shown are the mean \pm S.E.M., $n=20-22$ for control groups and rosiglitazone-treated groups, depending on the assay. 
effective TZD concentration reached at the level of the osteoclast. It would be anticipated that the observed changes in osteoblast parameters would produce parallel compensatory changes in osteoclast activity. Maintenance of appropriate bone mass depends upon the precise balance of bone formation and bone resorption. Balancing bone resorption and formation is centered on the ability of osteoblastic cells not only to form bone but to also regulate the rate of osteoclast differentiation (Suda et al. 1992). Here, the apparent unaltered nature of osteoclastic parameters may indeed be indicative of a persistent bone resorptive activity contributing to the observed decrease in bone mass. It is likely therefore, that rosiglitazone uncouples osteoblast-osteoclast cross talk during the bone remodeling process.

Controversy exists with regard to BMD changes in patients with type 2 diabetes mellitus (reviewed in LeidigBruckner \& Ziegler 2001). On one hand, hyperinsulinemia and relatively high BMI are protective against bone loss in type 2 diabetes mellitus. On the other, increased calciuria and decreased osteoblastic function due to hyperglycemia may lead to deterioration of bone mass (Terada et al. 1998). Considering the likelihood that patients with type 2 diabetes mellitus may potentially be at a somewhat higher risk of developing osteoporosis, treatment with TZDs could increase this risk further. The risk of deleterious effects by these agents on bone would require further investigation in the clinical setting (Quesada-Gomez \& Serrano-Alferez 2001). Nevertheless, our findings would indicate that more awareness of the risks could help in the prevention of osteoporosis in diabetic patients treated with TZDs. This could be accomplished by instituting timely and appropriate management for the prevention and treatment of osteoporosis in these patients. Of greater concern may be the advocated use of TZDs in young women with polycystic ovary syndrome and in individuals with other insulin resistance states (Day 1999) at a time of peak bone mass accretion. As illustrated by our study, the anticipated increase of BMD over time was profoundly hindered by rosiglitazone, suggesting that caution should be exercised when TZDs are administered in these groups of patients.

In summary, rosiglitazone administration in vivo leads to an imbalance in bone remodeling, in part by promoting osteoblast and osteocyte apoptosis. This in turn, has deleterious consequences on bone formation and ultimately on trabecular bone volume and BMD. These findings and the ever-increasing widespread use of TZDs in patients with type 2 diabetes mellitus and other insulinresistant states, strongly argues for prospective clinical studies that will address the complex effects of this class of oral antidiabetic agents on skeletal homeostasis.

\section{Acknowledgements}

The technical assistance of $\mathrm{H} \mathrm{Li}$ with the analysis of bones is greatly appreciated. This work was supported by grants from the Canadian Institutes of Health Research (CIHR). Support for MAS has been provided by the Medical Student Summer Research Bursary Award Program, Faculty of Medicine, McGill University. ACK is a recipient of the CIHR Scientist Award.

\section{References}

Adams M, Montague CT, Prins JB, Holder JC, Smith SA, Sanders L, Digby JE, Sewter CP, Lazar MA, Chatterjee VK \& O'Rahilly S 1997 Activators of peroxisome proliferator-activated receptor gamma have depot-specific effects on human preadipocyte differentiation. Journal of Clinical Investigation 100 3149-3153.

Bishop-Bailey D \& Hla T 1999 Endothelial cell apoptosis induced by the peroxisome proliferator-activated receptor (PPAR) ligand 15-deoxy- $\Delta 12,14$-prostaglandin J2. Journal of Biological Chemistry 274 17042-17048.

Boden G, Cheung P, Mozzoli M \& Fried SK 2003 Effect of thiazolidinediones on glucose and fatty acid metabolism in patients with type 2 diabetes. Metabolism 52 753-759.

Bruemmer D, Yin F, Liu J, Berger JP, Sakai T, Blaschke F, Fleck E, Van Herle AJ, Forman BM \& Law RE 2003 Regulation of the growth arrest and DNA damage-inducible gene 45 (GADD45) by peroxisome proliferator-activated receptor gamma in vascular smooth muscle cells. Circulation Research 93 38-47.

Camp HS, Li O, Wise SC, Hong YH, Frankowski CL, Shen X, Vanbogelen R \& Leff T 2000 Differential activation of peroxisome proliferator-activated receptor-gamma by troglitazone and rosiglitazone. Diabetes 49 539-547.

Chang TH \& Szabo E 2000 Induction of differentiation and apoptosis by ligands of peroxisome proliferator-activated receptor $\gamma$ in non-small cell lung cancer. Cancer Research 60 1129-1138.

Chinetti G, Griglio S, Antonucci M, Torra IP, Delerive P, Majd Z, Fruchart JC, Chapman J, Najib J \& Staels B 1998 Activation of proliferator-activated receptors $\alpha$ and $\gamma$ induces apoptosis of human monocyte-derived macrophages. Journal of Biological Chemistry 273 25573-25580.

Day C 1999 Thiazolidinediones: a new class of antidiabetic drugs. Diabetic Medicine 16 179-192.

De Vos P, Lefebvre AM, Miller SG, Guerre-Millo M, Wong K, Saladin R, Hamann LG, Staels B, Briggs MR \& Auwerx J 1996 Thiazolidinediones repress ob gene expression in rodents via activation of peroxisome proliferator-activated receptor gamma. Journal of Clinical Investigation 98 1004-1009.

Ducy P, Amling M, Takeda S, Priemel M, Schilling AF, Beil FT, Shen J, Vinson C, Rueger JM \& Karsenty G 2000 Leptin inhibits bone formation through a hypothalamic relay: a central control of bone mass. Cell 100 197-207.

Eibl G, Wente MN, Reber HA \& Hines OJ 2001 Peroxisome proliferator-activated receptor gamma induces pancreatic cancer cell apoptosis. Biochemical and Biophysical Research Communications 287 522-529.

Elstner E, Muller C, Koshizuka K, Williamson EA, Park D, Asou H, Shintaku P, Said JW, Heber D \& Koeffler HP 1998 Ligands for peroxisome proliferator-activated receptor $\gamma$ and retinoic acid receptor inhibit growth and induce apoptosis of human breast cancer cells in vitro and in BNX mice. PNAS 95 8806-8811.

Friedenstein AJ, Petrakova KV, Kurolesova AI \& Frolova GP 1968 Heterotopic of bone marrow. Analysis of precursor cells for osteogenic and hematopoietic tissues. Transplantation 6 230-247.

Gimble JM, Robinson CE, Wu X, Kelly KA, Rodriguez BR, Kliewer SA, Lehmann JM \& Morris DC 1996 Peroxisome proliferatoractivated receptor-gamma activation by thiazolidinediones induces adipogenesis in bone marrow stromal cells. Molecular Pharmacology $\mathbf{5 0}$ 1087-1094. 
Hauner H 2002 The mode of action of thiazolidinediones. Diabetes/Metabolism Research \& Reviews 18 S10-S15.

Heaney AP, Fernando M \& Melmed S 2003 PPAR- $\gamma$ receptor ligands: novel therapy for pituitary adenomas. Journal of Clinical Investigation 111 1381-1388.

Hu E, Tontonoz P \& Spiegelman BM 1995 Transdifferentiation of myoblasts by the adipogenic transcription factors PPAR gamma and C/EBP alpha. PNAS 92 9856-9860.

Jackson SM \& Demer LL 2000 Peroxisome proliferator-activated receptor activators modulate the osteoblastic maturation of MC3T3-E1 preosteoblasts. FEBS Letters 471 119-124.

Kawai T, Takei I, Oguma Y, Ohashi N, Tokui M, Oguchi S, Katsukawa F, Hirose H, Shimada A, Watanabe K \& Saruta T 1999 Effects of troglitazone on fat distribution in the treatment of male type 2 diabetes. Metabolism 48 1102-1107.

Kelly IE, Han TS, Walsh K \& Lean ME 1999 Effects of a thiazolidinedione compound on body fat and fat distribution of patients with type 2 diabetes. Diabetes Care 22 288-293.

Kuznetsov SA, Mankani MH, Gronthos S, Satomura K, Bianco P \& Robey PG 2001 Circulating skeletal stem cells. Journal of Cell Biology 153 1133-1140.

Lecka-Czernik B, Gubrij I, Moerman EJ, Kajkenova O, Lipschitz DA, Manolagas SC \& Jilka RL 1999 Inhibition of Osf2/Cbfa1 expression and terminal osteoblast differentiation by PPARgamma2. Journal of Cellular Biochemistry 74 357-371.

Lecka-Czernik B, Moerman EJ, Grant DF, Lehmann JM, Manolagas SC \& Jilka RL 2002 Divergent effects of selective peroxisome proliferator-activated receptor g2 ligands on adipocyte versus osteoblast differentiation. Endocrinology 143 2376-2384.

Lehmann JM, Moore LB, Smith-Oliver TA, Wilkison WO, Willson TM \& Kliewer SA 1995 An antidiabetic thiazolidinedione is a high affinity ligand for peroxisome proliferator-activated receptor gamma (PPAR gamma). Journal of Biological Chemistry 270 12953-12956.

Leidig-Bruckner G \& Ziegler R 2001 Diabetes mellitus a risk for osteoporosis? Experimental and Clinical Endocrinology and Diabetes 109 S493-S514.

Leung WK, Bai AH, Chan VY, Yu J, Chan MW, To KF, Wu JR, Chan KK, Fu YG, Chan FK \& Sung JJ 2004 Effect of peroxisome proliferator activated receptor gamma ligands on growth and gene expression profiles of gastric cancer cells. Gut $\mathbf{5 3}$ 331-338.

Lopez-De Leon A \& Rojkind M 1985 A simple micromethod for collagen and total protein determination in formalin-fixed paraffin-embedded sections. Journal of Histochemistry and Cytochemistry 33 737-743.

Malinowski JM \& Bolesta S 2000 Rosiglitazone in the treatment of type 2 diabetes mellitus: a critical review. Clinical Therapentics $\mathbf{2 2}$ $1151-1168$

Miao D, Bai X, Panda D, McKee M, Karaplis A \& Goltzman D 2001 Osteomalacia in hyp mice is associated with abnormal phex expression and with altered bone matrix protein expression and deposition. Endocrinology 142 926-939.

Miao D, He B, Karaplis AC \& Goltzman D 2002 Parathyroid hormone is essential for normal fetal bone formation. Journal of Clinical Investigation 109 1173-1182.

Miao D \& Scutt A 2002 Histochemical localization of alkaline phosphatase activity in decalcified bone and cartilage. Journal of Histochemistry and Cytochemistry $\mathbf{5 0} 333-340$.

Mori Y, Murakawa Y, Okada K, Horikoshi H, Yokoyama J, Tajima N \& Ikeda Y 1999 Effect of troglitazone on body fat distribution in type 2 diabetic patients. Diabetes Care 22 908-912.

Niemeyer NV \& Janney LM 2002 Thiazolidinedione-induced edema. Pharmacotherapy 22 924-929.

Norris AW, Chen L, Fisher SJ, Szanto I, Ristow M, Jozsi AC, Hirshman MF, Rosen ED, Goodyear LJ, Gonzalez FJ, Spiegelman BM \& Kahn CR 2003 Muscle-specific PPARg-deficient mice develop increased adiposity and insulin resistance but respond to thiazolidinediones. Journal of Clinical Investigation 112 608-618.
Nuttall ME \& Gimble JM 2000 Is there a therapeutic opportunity to either prevent or treat osteopenic disorders by inhibiting marrow adipogenesis? Bone 27 177-184.

Okazaki R 2000 Skeletal effects of thiazolidinediones. Nippon Rinsho 58 456-460.

Okazaki R, Miura M, Toriumi M, Taguchi M, Hirota Y, Fukumoto S, Fujita T, Tanaka K \& Takeuchi A 1999a Short-term treatment with troglitazone decreases bone turnover in patients with type 2 diabetes mellitus. Endocrine Journal 46 795-801.

Okazaki R, Toriumi M, Fukumoto S, Miyamoto M, Fujita T, Tanaka K \& Takeuchi Y $1999 b$ Thiazolidinediones inhibit osteoclast-like cell formation and bone resorption in vitro. Endocrinology 140 $5060-5065$.

Okura T, Nakamura M, Takata Y, Watanabe S, Kitami Y \& Hiwada K 2000 Troglitazone induces apoptosis via the p53 and Gadd45 pathway in vascular smooth muscle cells. European Journal of Pharmacology 407 227-235.

Owen M 1988 Marrow stromal stem cells. Journal of Cell Science (Suppl 10) 63-76.

Paulik MA \& Lenhard JM 1997 Thiazolidinediones inhibit alkaline phosphatase activity while increasing expression of uncoupling protein, deiodinase, and increasing mitochondrial mass in C3H10T1/2 cells. Cell and Tissue Research 290 79-87.

Petersen K, Krssak M, Inzucchi S, Cline G, Dufour S \& Shulman G 2000 Mechanism of troglitazone action in type 2 diabetes. Diabetes $49827-831$.

Quesada-Gomez JM \& Serrano-Alferez I 2001 Nonhypoglycemic effects of thiazolidinediones. Annals of Internal Medicine $\mathbf{1 3 5}$ 1007-1008.

Rosen ED, Sarraf P, Troy AE, Bradwin G, Moore K, Milstone DS, Spiegelman BM \& Mortensen RM 1999 PPAR gamma is required for the differentiation of adipose tissue in vivo and in vitro. Molecular Cell 4 611-617.

Rzonca SO, Suva LJ, Gaddy D, Montague DC \& Lecka-Czernik B 2004 Bone is a target for the anti-diabetic compound rosiglitazone. Endocrinology 145 401-406.

Satoh N, Ogawa Y, Usui T, Tagami T, Kono S, Uesugi H, Sugiyama H, Sugawara A, Yamada K, Shimatsu A, Kuzuya H \& Nakao K 2003 Antiatherogenic effect of pioglitazone in type 2 diabetic patients irrespective of the responsiveness to its antidiabetic effect. Diabetes Care 26 2493-2499.

Schwartz AV, Sellmeyer DE \& Feingold KR 2002 Thiazolidinedione (TZD) use and bone density in older adults with diabetes. Diabetes 51 abstract 237.

Shao D \& Lazar MA 1997 Peroxisome proliferator activated receptor gamma, CCAAT/enhancer-binding protein alpha, and cell cycle status regulate the commitment to adipocyte differentiation. Journal of Biological Chemistry 272 21473-21478.

Shimizu H, Tsuchiya T, Sato N, Shimomura Y, Kobayashi I \& Mori M 1998 Troglitazone reduces plasma leptin concentration but increases hunger in NIDDM patients. Diabetes Care 21 1470-1474.

Suda T, Takahashi N \& Martin TJ 1992 Modulation of osteoclast differentiation. Endocrine Reviews 13 66-80.

Takahashi N, Okumura T, Motomura W, Fujimoto Y, Kawabata I \& Kohgo Y 1999 Activation of PPAR $\gamma$ inhibits cell growth and induces apoptosis in human gastric cancer cells. FEBS Letters $\mathbf{4 5 5}$ $135-139$.

Terada M, Inaba M, Yano Y, Hasuma T, Nishizawa Y, Morii H \& Otani S 1998 Growth-inhibitory effect of a high glucose concentration on osteoblast-like cells. Bone 22 17-23.

Tontonoz P, Hu E, Graves RA, Budavari AI \& Spiegelman BM 1994 mPPAR gamma 2: tissue-specific regulator of an adipocyte enhancer. Genes and Development 8 1224-1234.

Tornvig L, Mosekilde L, Justesen J, Falk E \& Kassem M 2001 Troglitazone treatment increases bone marrow adipose tissue volume but does not affect trabecular bone volume in mice. Calcified Tissue International 69 46-50. 
Watanabe S, Takeuchi Y, Fukumoto S, Fujita H, Nakano T \& Fujita T 2003 Decrease in serum leptin by troglitazone is associated with preventing bone loss in type 2 diabetic patients. Journal of Bone and Mineral Metabolism 21 166-171.

Yokoyama Y, Okubo T, Kano I, Sato S \& Kano K 2003 Induction of apoptosis by mono(2-ethylhexyl)phthalate (MEHP) in U937 cells. Toxicology Letters 144 371-381.

Zhang B, Berger J, Zhou G, Elbrecht A, Biswas S, White-Carrington S, Szalkowski D \& Moller DE 1996 Insulin- and mitogen-activated protein kinase-mediated phosphorylation and activation of peroxisome proliferator-activated receptor gamma. Journal of Biological Chemistry 271 31771-31774.

Zhu Y, Qi C, Korenberg JR, Chen XN, Noya D, Rao MS \& Reddy JK 1995 Structural organization of mouse peroxisome proliferator-activated receptor gamma (mPPAR gamma) gene: alternative promoter use and different splicing yield two mPPAR gamma isoforms. PNAS 92 7921-7925.

Received 10 June 2004

Accepted 26 July 2004 